Neurochemical Research, Vol. 4, No. 5, 1079

\title{
AGE-DEPENDENT CHANGES IN THE SPECIFICITY OF tRNA METHYLTRANSFERASES IN THE CEREBELLUM OF THE ICTERIC AND NONICTERIC GUNN RAT
}

\author{
Jacques Dainat, ${ }^{1,3,4}$ F. De Balbian Verster, ${ }^{2}$ R. Zand, ${ }^{2}$ \\ AND O. Z. SELLINGER ${ }^{1,5}$ \\ ${ }^{1}$ Laboratory of Neurochemistry, Mental Health Research Institute \\ ${ }^{2}$ Division of Biophysics, Institute of Science and Technology \\ and \\ ${ }^{3}$ Department of Biological Chemistry \\ University of Michigan, Ann Arbor, Michigan 48109
}

Accepted January 29, 1979

\begin{abstract}
The activity of tRNA methyltransferases present in the cerebellum of 6- and 21day-old nonicteric and icteric Gunn rats was compared using purified $E$. coli tRNAs as substrates. At 6 days the tRNA methyltransferases of the icteric animals were significantly more effective in methylating tRNA ${ }^{\mathrm{Glu}_{2}}$ and tRNA ${ }^{\text {Phe }}$ than were those of their nonicteric counterparts. This relationship reversed itself at 21 days. The action of the tRNA methyltransferases from the 6-day-old icteric animals led to higher proportions of 1-methyladenine in tRNA ${ }^{\mathrm{Glu} \mathbf{u}_{2}}$ and tRNA $\mathrm{A}^{\text {Phe }}$ than were obtained using the corresponding enzymes of the nonicteric animals. The proportion of $N^{2}$-methylguanine was also higher, yet only in tRNA ${ }^{\text {tMet }}$ and not in tRNA ${ }^{\text {Phe }}$. The study reveals much more extensive fluctuations in the activity and in the substrate recognition specificity among the cerebellar tRNA methyltransferases of the icteric than among those of the nonicteric controls during the crucial 6-21 day period of cerebellar development.
\end{abstract}

\section{INTRODUCTION}

The insertion of the methyl group into tRNA and/or tRNA precursor molecules $(1-5)$ is the principal posttranslational modification undergone

${ }^{4}$ Present address: Laboratoire de Neuroendocrinologie, Université des Sciences et Techniques du Languedoc, Montpellier, Cedex, 34, France.

${ }^{5}$ Address correspondence to $\mathrm{O} . \mathrm{Z}$. S. 
by this family of ribonucleic acids during their maturation into functionally competent molecules. In the developing rat brain, homologous tRNA methylation was recently shown to remain active for as long as 3-4 weeks postnatally (6-7), suggesting that tRNA methylation may be a useful biochemical marker of neural maturation. When homologous tRNA methylation was compared in the developing cerebral cortex and cerebellum $(8,9)$ of the rat, specificity differences between the tRNA methyltransferases of each brain region were uncovered (9). Moreover, the patterns of heterologous methylation by tRNA methyltransferases of Purkinje and granule cells were found to differ significantly (9), indicating that tRNA methyltransferases may be endowed with cell-specific substrate recognition properties.

In an attempt to establish whether, in addition to being a significant modifying process during normal cerebellar development, tRNA methylation "marks" abnormal cerebellar development, we compare this process in the developing cerebella of the Gunn rat, a mutant Wistar animal characterized phenotypically by massive hyperbilirubinemia and by an apparent cerebellar hypoplasia, by determining the activity and specificity of cerebellar tRNA methyltransferases in the 6- and 21-day-old icteric, homozygous Gunn animal to those of its nonicteric, heterozygous littermates. It has been shown previously (10) that icteric cerebella weigh less than normal cerebella and that bilirubin inhibits the incorporation of amino acids into cerebellar protein in vitro $(11,12)$. More recently, Yamada et al. (13) concluded that chronologically the development of Purkinje cells is affected first in the Gunn rat and is then followed by a reduction in thymidine kinase activity (14) and DNA synthesis $(13,15)$. These authors also showed that in the Gunn cerebellum hypoplasia appears to be achieved by day 20 , when normal cell proliferation is virtually complete, and that the cerebellar levels of bilirubin do not exceed those found in several other brain regions visibly unaffected by kernicterus (16).

\section{EXPERIMENTAL PROCEDURE}

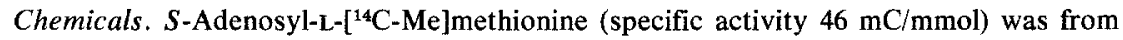
Centre d'Energie Atomique, Saclay, France, sold through Research Products Intern. Corp. (Elk Grove Village, Illinois), the $\left[{ }^{12} \mathrm{C}\right]$ methyl bases were from Sigma Chemical Co. (St. Louis, Missouri) or Cyclo Corp. (Los Angeles, California), E. coli tRNA W (molecular weight 25,000) from Schwarz-Mann (Orangeburg, New York), E. coli K 12 specific tRNAs were from Miles Laboratories, (Elkhart, Indiana), the tissue solubilizer PCS was from Searle (Arlington Heights, Illinois), and $S$-adenosyl-L-methionine (hydrogen sulfate) was from Boehringer-Mannheim (Indianapolis, Indiana). 
Animals. The Gunn animals were from our colony. The animals were defined as icteric or nonicteric on the basis of their skin color on day 1 (yellow-pink, icteric; pink, nonicteric).

Methods. (a) Preparation of Cerebellar tRNA Methyltransferases. Cerebella were obtained at 6 and 21 days. The tissue was homogenized in 3.5 vol of ice-cold $10 \mathrm{mM}$ tris- $\mathrm{HCl}$ buffer, $\mathrm{pH} 7.5$, containing $1 \mathrm{mM}$ dithiothreitol and $0.1 \mathrm{mM}$ EDTA. All subsequent operations were at $4^{\circ} \mathrm{C}$. The homogenates were centrifuged at $165,000 \mathrm{~g}$ for $150 \mathrm{~min}$, and the clear supernatants were used as the source of the total tissue complement of tRNA methyltransferases.

(b) Assay of tRNA Methyltransferase Activity. The incubation mixture contained in a total volume of $0.3 \mathrm{ml}: 30 \mu \mathrm{mol}$ tris- $\mathrm{HCl}$ buffer, $\mathrm{pH} 8.6,300 \mathrm{nmol}$ dithiothreitol, $6 \mathrm{nmol} S$ adenosyl-L-[ $\left[{ }^{14} \mathrm{C}-\mathrm{Me}\right]$ methionine $(0.1 \mu \mathrm{Ci}), 0.8-1.3 \mathrm{mg}$ cerebellar protein, $20 \mu \mathrm{g}$ tRNA, and $2.5 \mathrm{mM}$ spermidine. Incubation was at $37^{\circ} \mathrm{C}$ for $60 \mathrm{~min}$, and the reaction was stopped by the addition of 1 vol $88 \%(\mathrm{w} / \mathrm{v})$ phenol in $0.1 \mathrm{M} \mathrm{Na}$ acetate, $\mathrm{pH} 5.1$. After phenolization and the addition of $100 \mu \mathrm{g}$ carrier bulk $E$. coli tRNA, total tRNA was precipitated from the aqueous phase by the addition of $2.5 \mathrm{vol}$ absolute ethanol, and the suspension allowed to stand at $-20^{\circ} \mathrm{C}$ overnight. After centrifugation, the final tRNA pellet was suspended in 1.5 $\mathrm{ml}$ water, and an aliquot was withdrawn for counting.

(c) Chromatography of the $\left[{ }^{14} \mathrm{C}-\mathrm{Me}\right]$ Bases. The hydrolysis of the $\left[{ }^{14} \mathrm{C}\right]$ tRNA in trifluoroacetic acid and the separation of the resulting $\left[{ }^{14} \mathrm{C}-\mathrm{Me}\right]$ bases by means of high-performance liquid chromatography were as described previously $(7,17)$.

Analytical. Protein was determined by the procedure of Lowry et al. (18). Serum bilirubin levels were determined by the procedure of Morin (19).

\section{RESULTS}

Cerebellar Weights. As briefly reported before (20) and as shown in more detail in Fig. 1, cerebellar weights (as percentage of the total brain weight) of the icteric and nonicteric individuals were continuously monitored over a 2-month period. At 6 days there was no discernible difference between the two groups, while at 21 days the cerebellar weight of most but by no means all icteric animals fell below nonicteric values. We repeatedly found that the cerebellar weight of some icteric animals remained within the nonicteric weight range, despite the fact that the serum bilirubin levels (19) far exceeded normal levels in all icteric animals, without exception.

tRNA Methyltransferase Activity. The capacity of the icteric and nonicteric cerebellar tRNA methyltransferases to methylate individual $E$. coli tRNAs was compared at 6 and 21 days, and the results are shown in Table I. Although tRNA ${ }^{\mathrm{fmet}}$ was a much more suitable substrate than either tRNA ${ }^{\mathrm{Glu}_{2}}$ or tRNA ${ }^{\text {Phe }}$, its methylation declined with age in both groups of animals by an approximately equal extent. The methylation of tRNA ${ }^{\mathrm{Glu}_{2}}$ was significantly higher in the icteric cerebella at 6 days; by 21 days it stabilized in both groups at closely similar levels. The methylation of tRNA ${ }^{\text {Phe }}$ exhibited widely different patterns, increasing in the nonic- 


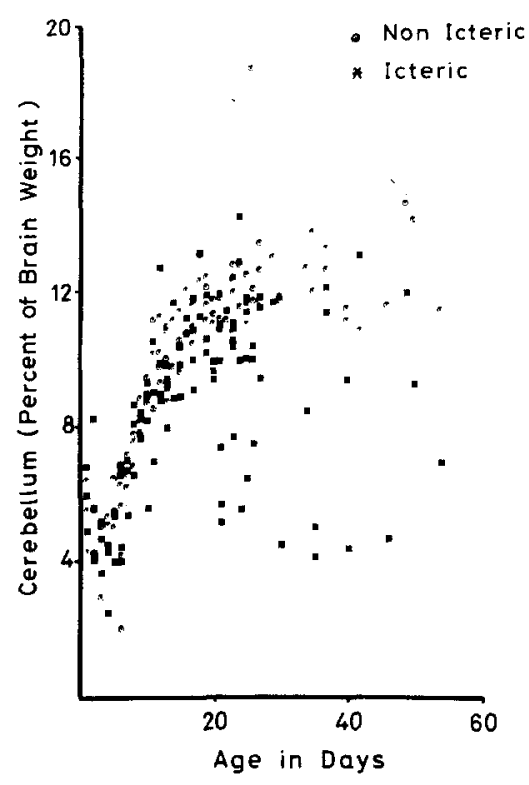

FIg. 1. Cerebellar development in the icteric and nonicteric Gunn rat. Cerebella were excised from the icteric (yellow-pink skin on day 1) and nonicteric (pink skin on day 1) rats, and their weight was determined. The ordinate values refer to the percentage of the total brain (cerebellum plus rest of brain) weight represented by the cerebellum.

teric and decreasing in the icteric animals, suggesting diametrically opposite developmental trends for the cerebellar tRNA methyltransferases involved in its methylation (see Table II) in the two groups of animals.

Methylation of Individual tRNA Bases. Since in brain tissue $(9,21,22)$, as in other eukaryote systems, $E$. coli $\mathrm{tRNA}^{\mathrm{Glu}_{2}}$ and tRNA ${ }^{\mathrm{Phe}}$ are, re-

TABLE I

Cerebellar tRNA Methyltransferase ACTIVITy of ICTERIC AND NONICTERIC RATS ${ }^{a}$

\begin{tabular}{|c|c|c|c|c|c|c|}
\hline \multirow[b]{2}{*}{ Substrate } & \multicolumn{3}{|c|}{6 days } & \multicolumn{3}{|c|}{21 days } \\
\hline & Non-Ic & Ic & Ic/Non-Ic & Non-Ic & Ic & Ic/Non-Ic \\
\hline tRNA, bulk & 5,000 & 4,300 & 0.86 & 3,100 & 2,000 & 0.64 \\
\hline tRNA $^{\text {fMet }}$ & 18,000 & 16,800 & 0.93 & 8,300 & 6,600 & 0.77 \\
\hline $\mathrm{tRNA}^{\mathrm{Glu_{2 }}}$ & 7,000 & 13,200 & 1.88 & 6,000 & 5,100 & 0.85 \\
\hline tRNA $^{\text {Phe }}$ & 1,300 & 2,000 & 1.53 & 2,800 & 900 & 0.32 \\
\hline
\end{tabular}

${ }^{a}$ Values are in dpm $\left[{ }^{14} \mathrm{C}-\mathrm{Me}\right]-\mathrm{tRNA} / \mathrm{mg}$ protein. They represent means of three experiments, varying less than $15 \%$. Non-Ic, nonicteric; Ic, icteric. 


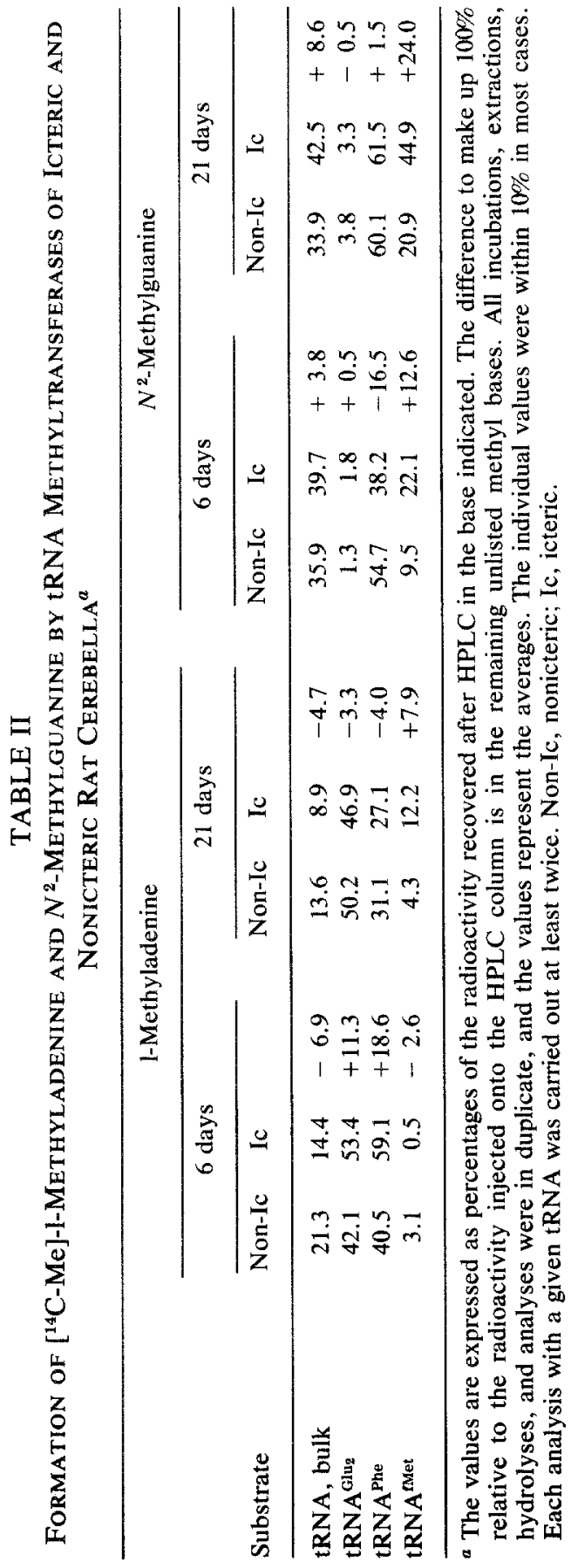


spectively, the preferred substrates of tRNA (adenine-1)-methyltransferase and tRNA (guanine- $N^{2}$ )-methyltransferase, the formation of 1-methyladenine and $N^{2}$-methylguanine was compared in 6- and 21-day-old icteric and nonicteric cerebella. tRNA ${ }^{\mathrm{fMet}}$ was also used for this purpose, since it has been shown to be an effective substrate for both of the above mentioned tRNA methyltransferases $(22,23)$. Table II shows that the formation of 1-methyladenine in tRNA ${ }^{\mathrm{Clu}_{2}}$ accounted for $42-55 \%$ of the total $\left[{ }^{14} \mathrm{C}-\mathrm{Me}\right]$ bases formed. In tRNA ${ }^{\text {Phe }}$, on the other hand, 1-methyladenine formation decreased with age in both groups, yet this age-related decrease was quantitatively more significant in the icteric cerebella. Furthermore, the icteric condition appeared to facilitate the recognition of tRNA $^{\text {Phe }}$ by the tRNA (adenine-1)-methyltransferase at 6 days but not at 21 days. Surprisingly, tRNA ${ }^{\mathrm{fMet}}$ was a relatively ineffective substrate for the cerebellar tRNA (adenine-1)-methyltransferase of the Gunn rat (22, 24,25).

The formation of $N^{2}$-methylguanine (Table II) was highest with tRNA $^{\text {Phe }}$ as substrate, and in the nonicteric cerebella there was no change in its formation between days 6 and 21. In the icteric cerebellum, on the other hand, this reaction was less significant at 6 days, yet by day 21 it attained nonicteric levels. The formation of $N^{2}$-methylguanine in tRNA ${ }^{\mathrm{fMet}}$ appeared greatly stimulated (26) in the icteric animal relative to controls, yielding a tRNA ${ }^{\mathrm{fmet}}$ containing $24 \%$ more $\left[{ }^{14} \mathrm{C}-\mathrm{Me}\right]-N^{2}$-methylguanine within its structure than the "normal" tRNA ${ }^{\mathrm{fMet}}$.

\section{DISCUSSION}

Sawasaki et al. (10) have previously determined that the weight of the cerebellum in the homozygous Gunn rat increases normally up to about 8 days and then abruptly subsides. These authors also showed that total cerebellar DNA follows a similar course. The sudden drop in cerebellar weight was not attributed to the higher than normal cerebellar bilirubin levels, but instead appeared to correlate with the decrease in cerebellar thymidine kinase activity $(14,27)$ which occurs as early as 6 days postnatally. It is noteworthy that Dainat and Rebière (28) found precursor incorporation into RNA and DNA of the cerebellum of the Wistar rat to be maximal at 6 and close to minimal at 21 days, a time when cerebellar development also nears completion $(13,29)$ and when homologous cerebellar tRNA methylation (examined in the Sprague-Dawley rat) is significantly different from its 6 day levels $(8,9)$.

The results shown in Fig. 1 confirm that at 6 days cerebellar weights are the same in the icteric and nonicteric animals, yet they place the occurrence of the weight reduction in the icteric animals at around 18-21 days. More significantly, several icteric animals were found to maintain 
normal cerebellar weights throughout the entire period examined, casting some doubt on the generally accepted notion that cerebellar weight loss is an obligatory correlate of kernicterus in the Gunn rat.

The heterologous methylation of tRNA by tRNA methyltransferases of the icteric and nonicteric cerebella (Table I) was significantly different at 6 vs. 21 days, particularly with tRNA ${ }^{\mathrm{Glu}_{2}}$ and tRNA ${ }^{\text {Phe }}$ as substrates. The methylation of these substrates was much higher when the enzymes were derived from 6-day-old icteric cerebella, yet by day 21 it returned to half-control levels, thereby causing a reversal of the Ic/Non-Ic ratio from 1.88 and 1.53 on day 6 to 0.85 and 0.32 on day 21 . It is of interest that the methylation of tRNA ${ }^{\mathrm{fMet}}$ remained stable in both groups.

The further analysis of the effect of the kernicteric condition on two of the base-specific methyltransferases, namely tRNA (adenine-1)-methyltransferase and tRNA (guanine- $N^{2}$ )-methyltransferase (Table II) revealed that, in general, the two activities were affected in different ways and to different extents, depending largely on the nature of the tRNA substrate. The formation of $\left[{ }^{3} \mathrm{H}\right.$-methyl]-l-methyladenine in tRNA ${ }^{\mathrm{Glu}_{2}}$ and tRNA ${ }^{\text {Phe }}$ was much higher when the enzyme was derived from the icteric animals, but only at 6 days. Conversely, $\left[{ }^{3} \mathrm{H}\right.$-methyl $]-N^{2}$-methylguanine formation in $\mathrm{tRNA}^{\text {Phe }}$, but not in $\mathrm{tRNA} \mathrm{f}^{\mathrm{fMet}}$, was less effective when catalyzed by the enzyme of the icteric animals, but again only at 6 days. The insertion of the $\left[{ }^{3} \mathrm{H}\right.$-methyl] group(s) into the guanine(s) of tRNA ${ }^{\text {fMet }}$, on the other hand, appeared to be twice as effective when the icteric enzymes were used than when controls were used, both at 6 and at 21 days, suggesting that tRNA (guanine- $N^{2}$ )-methyltransferase of icteric cer-ebellar cells recognizes $E$. coli $\mathrm{tRNA}^{\mathrm{fMet}}$ as a more suitable substrate than does its cognate "nonicteric" enzyme. It would be of great interest to know whether in the icteric cerebellum the "changed" tRNA (guanine$N^{2}$ )-methyltransferase resides in the normal granule cells (13), in the abnormal Purkinje cells $(9,13)$, in both cell types, or in glial cells $(26)$ and whether its apparently excessive ability to methylate the initiator tRNA, tRNA $^{\mathrm{fMet}}$ but not tRNA ${ }^{\text {Phe }}$, another of its natural substrates (22), causally relates to the cerebellar hypoplasia which accompanies kernicterus.

\section{ACKNOWLEDGMENTS}

This work was supported by Grants NINCDS-06294 (O. Z. S.) and 11923 (R. Z.).

\section{REFERENCES}

1. NAU, F. 1976. The methylation of tRNA. Biochimie 58:629-645.

2. Agris, P. F., and Soll, D. 1977. The modified nucleosides in transfer RNA. Pages 321-344, in Nucleic Acid and Protein Recognition. Academic Press, New York. 
3. Caboche, M., and Bachellerie, J.-P. 1977. RNA methylation and control of eukaryotic RNA biosynthesis. Eur. J. Biochem. 74:19-29.

4. Munns, T. W., and Sims, H. F. 1975. Methylation and processing of transfer ribonucleic acid in mammalian and bacterial cell. J. Biol. Chem. 250:2143-2149.

5. Elahi, E., and Sellinger, O. Z. 1979. The post-natal methylation of tRNA in brain: Evidence for the methylation of precursor tRNA. Biochem. J. 177:381-384.

6. Cummins, C. J., Salas, C. E., and Sellinger, O. Z. 1975. The homologous methylation of tRNA in rat brain. Brain Res. 96:406-412.

7. Salas, C. E., Cummins, C. J., and Sellinger, O. Z. 1976. The developmental pattern of homologous and heterologous tRNA methylation in rat brain: Differential effects of spermidine. Neurochem. Res. 1:369-384.

8. Sellinger, O. Z., Dainat, J, and Salas, C. E. 1977. The relationship of tRNA methylation to brain protein synthesis during cortical and cerebellar development. Pages 55-70, in Gispen, W. H., LaJtha, A., and Roberts, S. (eds.), Mechanisms, Regulation and Special Functions of Protein Synthesis in Brain. Elsevier/North-Holland, Amsterdam.

9. Dainat, J., and Sellinger, O. Z. 1979. Cerebellar tRNA methyltransferases: A developmental study. Brain Res. (in press).

10. Sawasaki, Y., Yamada, N., and Nakajima, H. 1976. Developmental features of cerebellar hypoplasia and brain bilirubin levels in a mutant (Gunn) rat with hereditary hyperbilirubinemia. J. Neurochem. 27:577-583.

11. Greenfield, S., and Nandi Majumdar, A. P. 1974. Bilirubin encephalopathy: Effect on protein synthesis in the brain of the Gunn rat. J. Neurol. Sci. 22:83-89.

12. GuRBA, P. E., and ZAND, R. 1974. Bilirubin binding to myelin basic protein, histones and its inhibition in vitro of cerebellar protein synthesis. Biochem. Biophys. Res. Commun. 58:1142-1147.

13. Yamada, N., Sawasaki, Y, and Nakajima, H. 1977. Impairment of DNA synthesis in Gunn rat cerebellum. Brain Res. 126:295-307.

14. Yamada, N., Sawasaki, Y., and Nakajima, H. 1976. Studies on kernicterus. V. Decreased thymidine kinase activity in Gunn rat cerebellum. Proc. Jpn. Acad. 52:148151 .

15. Yamada, N., SAWASAKI, Y., and Nakajima, H. 1973. Studies on kernicterus. II. Impairment of DNA synthesis in homozygous Gunn rats. Proc. Jpn. Acad. 49:846-851.

16. SaWaSaKi, Y., Mori, E., Yamada, N., and NAKajima, H. 1976. Studies on kernicterus. VII. Autoradiographic study of cerebellar hypoplasia in Gunn rat. Proc. Jpn. Acad. 52:517-520.

17. Salas, C. E., and Sellinger, O. Z. 1977. Rapid, quantitative separation by highperformance liquid chromatography of methylated bases in transfer RNA. J. Chromatog. 133:231-236.

18. Lowry, O. H., Rosebrough, N. J., Farr, A. L., and Randall, R. J. 1951. Protein measurement with the Folin reagent. J. Biol. Chem. 193:265-275.

19. MoRIN, L. G. 1973. Improved stable diazonium salt procedure for determination of total serum bilirubin. Clin. Chim. Acta 47:111-112.

20. ZAND, R., and DE BALBIAN VERSTER, F. 1978. GABA and other biochemical changes in hyperbilirubinemic rat brain. Tr. Am. Soc. Neurochem. 9:142.

21. Salas, C. E., and Sellinger, O. Z. 1978. Methylation of E. coli transfer ribonucleic acids by a tRNA adenine-1-methyltransferase from rat brain cortex and bulk-isolated neurons. J. Neurochem. 31:85-91.

22. Dainat, J., Salas, C. E., and Sellinger, O. Z. 1978. Alteration of the specificity of brain tRNA methyltransferases and of the pattern of brain tRNA methylation in vivo by methionine sulfoximine. Biochem. Pharmacol. 27:2655-2658. 
23. Spremulli, L. L., Agris, P. F., Brown, G. M., and Rajbhandary, U. L. 1974. Escherichia coli formylmethionine tRNA: Methylation of specific guanine and adenine residues catalyzed by HeLa cell tRNA methylases and the effect of these methylations on its biological properties. Arch. Biochem. Biophys. 162:22-37.

24. Glick, J. M., Averyhart, V. M., and Leboy, P. S. 1978. Purification and characterization of two tRNA-(guanine)-methyltransferases from rat liver. Biochim. Biophys. Acta 518:158-171.

25. Kraus, J. 1978. Recognition of individual Escherichia coli transfer ribonucleic acids by 1-adenine specific methyltransferase from rat liver. Biochem. J. 169:24?-249.

26. Salas, C. E., Ohlsson, W. G., and Sellinger, O. Z. 1977. The stimulation of cerebral $N^{2}$-methyl- and $\mathrm{N}_{2}{ }^{2}$-dimethyl guanine specific tRNA methyltransferases by methionine sulfoximine: An in vivo study. Biochem. Biophys. Res. Commun. 76:11071115.

27. Yamagami, S., Mori, K., and Kawakita, Y. 1972. Changes in thymidine kinase in the developing rat brain. $J$. Neurochem. 19:369-376.

28. Dainat, J., and Rebière, A. 1976. The change in the incorporation of $\left[6^{-24} \mathrm{C}\right]$-orotic acid in vivo into RNA and DNA in the cerebellum of young hypo- and hyperthyroid rats: comparative effects of hypo- and hyperthyroidism on cell multiplication. J. Neurochem. 26:941-950.

29. ReBière, A., and DAINAT, J. 1976. Etude ultrastructurale quantitative du péricaryon de la cellule de Purkinje et de son environnement chez le rat normal et hypothyroidien âgés de 21 jours. Exp. Brain Res. 25:511-527. 